\title{
SHOPPING TOURISM AS A FACTOR IN THE DEVELOPMENT OF PERIPHERAL AREAS ON THE EXAMPLE OF THE POLISH-UKRAINIAN BORDERLAND
}

\author{
Arkadiusz MALKOWSKI \\ West Pomeranian University of Technology in Szczecin; amalkowski@zut.edu.pl, \\ ORCID:0000-0003-2769-245X
}

\begin{abstract}
The progressing globalization process and the accompanying changes in the approach to the role of borders influence the perception of border areas. For decades, borderlands were treated as peripheral. In many cases it resulted in impeding the processes of socio-economic development, which further deepened the isolation and peripherality of those areas. The article presents selected results of research conducted by the author in the area of the Polish-Ukrainian borderland, related to shopping tourism. Shopping tourism is a significant factor in the development of peripheral areas. According to official statistics, as many as $94 \%$ of foreigners visiting Poland in 2017 declared shopping as the purpose of their visit. It was the Ukrainian citizens who spent the most on shopping in Poland in 2017. They spent over PLN 750 on the purchase of products and services per one person crossing the border. In the same period, Belarusians spent PLN 624 on purchases in Poland, Lithuanians PLN 532, Russians PLN 455, Germans PLN 461, Slovaks PLN 315, and Czechs PLN 285 per person. In the Polish-Ukrainian border area, 91\% of expenses of Ukrainian citizens in Poland are incurred at a distance of less than $50 \mathrm{~km}$ from the border ( $89 \%$ in an area up to $30 \mathrm{~km}$ ). This means that in an area within $50 \mathrm{~km}$ from the border with Ukraine, revenues related only to the shopping of Ukrainian citizens travelling to Poland amount to over PLN 6 billion. Expenses related to shopping tourism affect the development of entrepreneurship on the PolishUkrainian border.
\end{abstract}

Keywords: shopping tourism, border trade, peripheral area, Polish-Ukrainian borderland.

\section{Introduction}

In the contemporary world, borders are changing their functions. More and more often, they become a place of lively contact and cooperation between the communities divided by borders. A peculiar example of transition from isolation to integration are the borderlands in Europe. 
The increasing permeability of borders is a result of geopolitical transformations taking place in the integrating Europe (Miszczuk, 2013, Kosiedowski, 2008). This is conducive to the development of various types of activities, including those of a cross-border nature.

The Polish-Ukrainian borderland is a very interesting area for socio-economic research. Ukraine is Poland's strategic economic and political partner. Its location on the external border of the EU, as well as striving for strong integration with the EU Member States makes it the area of intense political, social, and economic contacts. A particular expression of that cooperation is commercial exchange. Its development is especially valuable for supporting the processes of socio-economic transformations in peripheral areas (Malkowska, 2014).

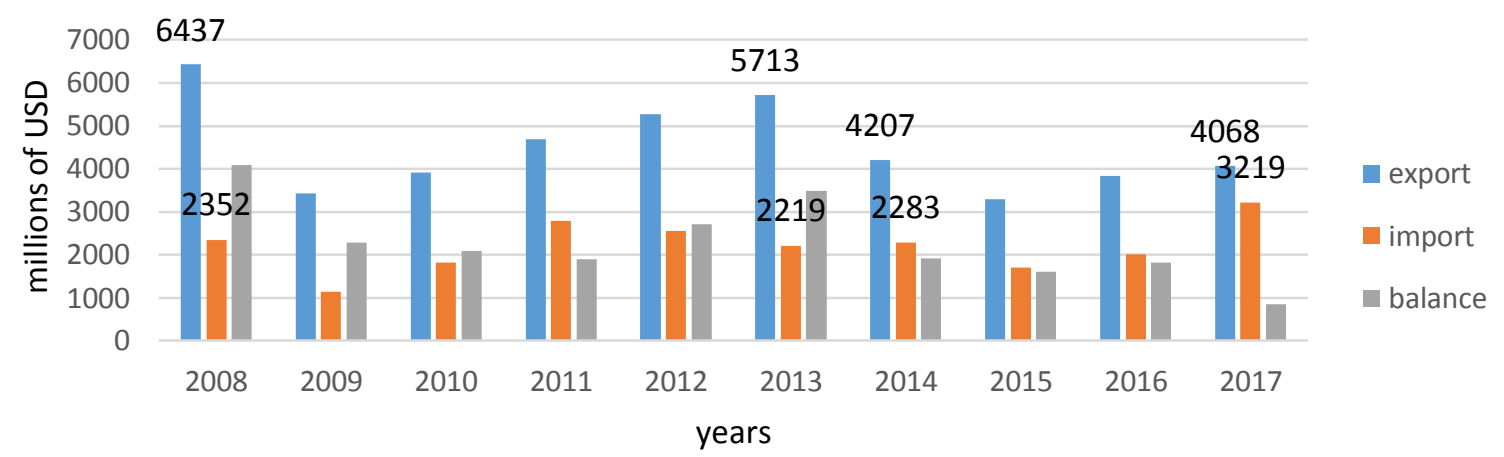

Figure 1. Commercial exchange between Poland and Ukraine in the years 2008-2017 (in millions of USD). Source: own study on the basis of data from the Main Statistical Office (GUS).

Among the European Union countries, Poland is the largest outlet for the Ukrainian economy. The conflict and crisis in Ukraine meant that in 2014 the value of sales of goods from Poland in Ukraine decreased by over $27 \%$ (Fig. 1). The increase in the volume of exports to Ukraine took place only in 2016, after a stronger opening of economies to Polish-Ukrainian contacts. This was the result of the entry into force of the Association Agreement signed between the EU and Ukraine. In 2107, an increase in exports of Polish goods sold in Ukraine was also noted.

Since 2015, Ukrainian exports to Poland have been steadily increasing. In 2017, exports of Ukrainian products to Poland increased by $89 \%$ compared to 2015 . It proves the opening of the markets of both countries to mutual contacts.

The structure of trade between Poland and Ukraine changes every year, but the most important products exported by Ukraine to Poland include:

- metallurgical products,

- agri-food products,

- mineral products.

The commodity structure of Polish exports to Ukraine in terms of the most important items is as follows:

- machinery industry products,

- chemical industry products,

- agri-food products. 
Cooperation between Poland and Ukraine is multifaceted. It concerns actions at the level of government as well as regional and local initiatives.

The development of cross-border cooperation on the Polish-Ukrainian border is an example of a difficult process of breaking administrative and mental barriers.

The complicated history of both nations, the isolating nature of the EU's external border, and the armed conflict in eastern Ukraine caused the Polish-Ukrainian border to become the "golden curtain" separating the rich countries of western Europe from the continent's eastern part.

In Polish consciousness, the Ukrainian border area is still perceived as "Polish borderland separated from the motherland". For many Ukrainians, this term has a pejorative character and is perceived as a manifestation of Polish political, settlement and cultural expansion carried out at the expense of the native Ukrainian population. This does not facilitate agreement and cooperation. It is often used to form extreme nationalist attitudes on both sides of the border.

Experiences in shaping cooperation between nations divided by borders invite to search for various forms of easing border regimes and creating opportunities for the development of friendly coexistence. One of such opportunities is the development of shopping tourism.

The increased flow of goods, services and people, facilitated by the increase in border permeability, positively impacts cooperation across borders. Border areas recognised for decades as peripheral, are becoming, owing to the development of economic contacts, bridges between countries and their communities. Growing trade in border areas is not only a dimension of globalization, but also of glocalization. The growing importance of regions and their independent economic development policy, favours activities supporting the development of cross-border trade, in which shopping tourism plays a large role.

\section{Purpose and research methods}

The purpose of the article is to present the changes in the role of Poland's eastern border and their impact on the development of shopping tourism. The presented research is part of a broader scientific project aimed at verifying the following hypothesis: "Shopping tourism is a significant factor in the development of peripheral areas". The research was conducted on the basis of data made available in public statistics, including those by Statistics Poland (GUS) and the Border Guards, and the analysis of the available literature on the subject. From the point of view of verifying the research hypothesis, it was a key issue to conduct research based on CATI methodology, which included 135 interviews with entrepreneurs from the Polish-Ukrainian border area. A survey was also conducted among local governments within a $50 \mathrm{~km}$ distance 
from the eastern border. The research was conducted from June to October 2017 and in September $2018^{1}$.

\section{Shopping tourism in border areas}

Border areas, due to their lower level of socio-economic development and remoteness from decision-making centres, are often described as peripheral territories (Ciok, 2000). The research conducted by the author indicates that border areas are usually characterised by highly unfavourable socio-economic features, and the change in the functions of borders is becoming a factor fuelling social and economic processes occurring in peripheral areas (Malkowski, 2015).

Shopping tourism is one of the factors that is directly related to changes in border functions and socio-economic development of the border area.

Globalization processes, universal access to information, and, above all, lifting customs and visa restrictions should be treated as factors conducive to the development of this form of leisure tourism. Numerous examples of cities and regions indicate that this type of tourism is more and more often perceived as an opportunity for additional income and socio-economic development (Barcelona, 2017; Hołderna-Mielcarek, and Majchrzak, 2007).

Observations of global trends indicate that shopping is becoming an important link in the tourist value chain as part of the global value chain (GVC) (UNWTO, 2014). This chain is created as the sum of activities undertaken by entrepreneurs aimed at delivering a product or service to the final recipient.

The United Nations World Tourism Organisation (UNWTO) defines shopping tourism as a modern form of tourism supported by people for whom the purchase of goods outside their usual environment is a determining factor for travel (UNWTO, 2014).

Border shopping tourism is defined as a shopping visit for residents of a neighbouring country, usually living in areas adjacent to borders (Studzińska, 2014).

In the literature on tourism, a number of different classifications relating to travel motives can be found (Rojek et al., 2002). The key to using shopping tourism as a development factor is to define the elements that influence the decision about making a purchase. The conducted research indicates that the decision to purchase is influenced by a variety of direct and indirect factors resulting from the conscious or unconscious needs of tourists (Tosun et al., 2007)

Timothy (2005) was the author of one of the classifications of motives for participation in shopping tourism that influenced the author's research in this field. He proposed the division of motives characteristic of shopping tourism into: products, reception areas, and prices.

\footnotetext{
${ }^{1}$ The research was conducted in the following poviats: Włodawa, Chełm, Hrubieszów, Tomaszów Lubelski, Lubaczów, Jarosław, Przemyśl, and Bieszczady.
} 
In the case of products that affect the decision to make a shopping trip, they may be unique products specific to the area, goods subject to more favourable tax and customs regulations (e.g. duty-free), as well as the width and depth of product ranges. The division proposed by Timothy should also be supplemented with services that, as in the case of products, are increasingly being exchanged as part of shopping tourism.

As far as the reception area is concerned, attention is paid to the special nature of the places where shopping tourism transactions are carried out. They can be seen as a whole, as it is in the case of Paris or Milan, which are identified with fashion capitals. This issue can also be perceived from a more local perspective, in which the motive for a trip to another country will be the desire to make a purchase in a border shopping centre or at a local market.

The motive that undoubtedly drives the decisions made by tourists visiting border areas are prices (Turner et.al., 2001). Thanks to the access to information enabling the comparison of prices for basic goods and services, the motive for the trip is not a traditional tourist destination, but above all the opportunity to buy a cheaper product or use a cheap service.

The awareness of various motives that tourists have and the growing understanding of the role of shopping for tourists in the development of the region's economy means that shopping tourism is becoming an important element of information policy, and even regional or local marketing (Hernik, 2014; Suhartanto, and Triyuni, 2016; Spierings, and Van der Velde, 2013).

Examples of Ceuta, the Canary Islands, or special duty free zones at airports or ferries indicate the desirability of developing a shopping offer targeted at tourists. Shopping tourism should be a vital element of the tourism policy implemented by regional and local authorities (Getz, 1993). It enables the development of and complements the existing tourist product of the region, increasing its attractiveness and creating its brand.

The development of services and product offer for retail clients is an element of shaping the quality of life of the residents in the borderland areas (Westwood, 2006). It enables meeting the key needs of the region's inhabitants. It can be an important factor in attracting customers from outside the region - shopping tourists (Yu, and Littrell, 2003).

Revenue related to additional expenses incurred by shopping tourists is an important source of income for part of the local community. Through tax revenues, they form an important part of regional budgets.

Therefore, according to the United Nations World Tourism Organisation, shopping tourism is part of a symbiotic partnership between the benefits obtained by the tourists and by the region (UNWTO, 2014).

The essence of this symbiosis is to create an attractive tourist product. A tourist product in the field of shopping tourism is a specific pool of goods and services available on the market that are purchased by consumers from outside the region. It can also be considered as a set of specific tangible and intangible benefits obtained by tourists. Increasingly, a tourist product is identified with innovative solutions designed to influence tourists' decisions (Mazur, 2012). 
It is therefore worth developing it, looking for new attractive elements forming the structure of the shopping tourism product. This concerns all its three levels, proposed by Altkorn (1996). These include:

1. the core of the product - the specific need that a tourist meets, in connection with a tourist trip,

2. real product - the actual subject of the transaction in which a tourist participates, becoming a consumer of a tourist product; a real product is a collection of services, material goods, and places that determine the nature of a product,

3. extended product - includes a set of additional, often hardly measurable benefits that a tourist obtains by purchasing a tourist product.

Thanks to the diversified structure of the shopping tourism product, individual regions can build their specific offer addressed to tourists. The universal nature of some of the elements that fit into the tourist product of the border region is also extremely attractive to its inhabitants, affecting the increase in the quality of life in the peripheral area.

The development of shopping tourism is possible when the regional policy includes in its premises activities supporting the creation of an attractive tourist product. Increasingly, the literature on the subject indicates the importance of other than typical tourist attractions of the region. Factors attracting tourists include, among others, shopping centers, which are often the main destination of tourist and shopping trips (Hołderna-Mielcarek, and Majchrzak, 2007). An example are border marketplaces along the Polish-German border, which during the economic transformation were one of the important factors in the development of border areas.

However, it should be remembered that the development of shopping tourism in border areas is closely correlated with the changing functions of the borders. Opening borders to the free movement of people, goods and capital is a prerequisite for thinking about developing a tourism product based on shopping tourism in the border area. In the case of restrictions on the freedom of border traffic, revenues from shopping tourism are decreasing. Therefore, liberalisation of border regulations and preparation of an attractive tourist product is the key to achieving success in the development of shopping tourism in border areas.

\section{Shopping tourism and the development of the Polish-Ukrainian borderland area}

The border between the Republic of Poland and Ukraine has existed formally since 24 August 1991, that is, since Ukraine gained independence. Until 1991, the current border with Ukraine was part of the border with the USSR and was of an extremely isolating nature. The length of the Polish-Ukrainian border is $535 \mathrm{~km}$. There are fourteen border crossings along it (eight via road and six via railway). Due to the busy border traffic, it is planned to create 
another seven border crossings. The Polish-Ukrainian border area covers Lublin and Podkarpackie voivodeships.

The dynamic integration processes taking place on the Polish-Ukrainian border significantly impact the activity of the borderland's residents and the character of the border region. The change in the role of the eastern border and increase in its permeability created the conditions for its regular crossing by border residents. In particular, this applies to the period of operation of the local border traffic agreement between Poland and Ukraine. The local border traffic agreement entered into force on July 1, 2009. Local border traffic is beneficial for residents of the area covered by the derogation from the Schengen visa regime. Entry into force has established a completely new border traffic system to which only residents of the border area are entitled. Facilitations related to the introduction of local border traffic result in the fact that borderland residents are increasingly willing to cross the border for shopping and tourist purposes (Malkowska, 2013; Więckowski, 2010).

Border traffic is an important factor influencing the socio-economic situation of the outermost, peripheral regions. According to the data of the Border Guard, in 2017 the estimated number of crossings at the Polish border was 287.1 million. Over 171.6 million foreigners and 115.5 million Poles crossed the borders. More than $74 \%$ of those crossing the border used the land border crossing points between Poland and the EU, and $12.5 \%$ crossed the EU's external border (the border with Russia, Belarus and Ukraine). Among foreigners crossing individual sections of the land border of Poland dominated the citizens of the neighbouring country. In the case of the section of the Polish-Ukrainian border, almost $97 \%$ of foreigners who crossed it were Ukrainian citizens.

The Polish border with Ukraine is the most frequently crossed external border of the European Union, located in Poland. According to data from border services in 2017, there were almost 6 times more checks on the Polish-Ukrainian border than on the Polish-Russian border and 2.5 times more than on the Polish-Belarusian border.

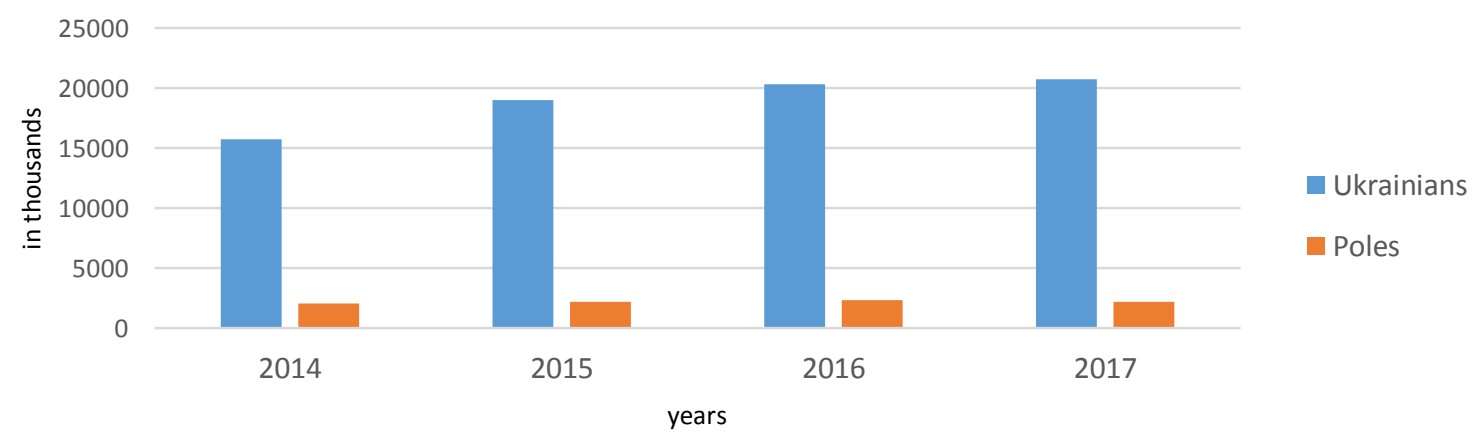

Figure 2. The volume of border traffic on the Polish-Ukrainian border in thousands of persons. Source: own study on the basis of data from Border Guards. 
The increase in border traffic with Ukraine is the effect of the implementation of the local border traffic agreement, the opening of the Polish labour market to Ukrainian employees, and the possibility for the residents of border areas to buy affordable products in Poland. According to estimates of the NBP Department of Statistics, in 2017, about 900,000 Ukrainian citizens stayed in Poland. In the first three quarters of 2017, these immigrants transferred over PLN 8.6 billion to Ukraine.

The research conducted by the author indicates a close relationship between the volume of border traffic of foreigners and the socio-economic situation of border areas. Surveys carried out showed that entrepreneurs based in the poviats located directly by the border revealed that the increase in border traffic had a positive effect on the economic situation in the region. The greatest impact of border traffic on the economic situation of the Polish-Ukrainian border region was indicated by entrepreneurs from poviats of the Podkarpackie voivodeship (96\% of responses). In the case of entrepreneurs from the poviats of Lubelskie voivodeship, the value of this indicator amounted to $94 \%$. According to respondents, the development of shopping tourism is an important factor influencing the growth of entrepreneurship of the inhabitants of the border area. $89 \%$ of the surveyed entrepreneurs had this view.

In 2017, the vast majority of foreigners crossed the border for a very short period of time. Over $84 \%$ of foreigners and $87 \%$ of Poles left and returned to their country in one day.

According to official statistics, as many as $94 \%$ of foreigners visiting Poland in 2017 declared shopping as the purpose of the visit. This clearly indicates the need for research on the impact of shopping tourism on the socio-economic development of regions. It should be noted that the percentage of visitors indicating shopping as the purpose of their visit to Poland increased, compared to 2014, by one percentage point.

Expenses of foreigners in Poland are treated as an additional capital injection, extremely important for the local economy. The area of the Polish-Ukrainian borderland is primarily an agricultural region with poorly developed industry and processing. The underdevelopment of the local economy mainly concerns areas located far away from regional growth centers such as Przemyśl and Lublin. The state of the economy of the Polish-Ukrainian border region is reflected in macroeconomic data on GDP per capita or unemployment rate - see Tab. 1.

Table 1.

Basic macroeconomic data for the eastern borderland of Poland in 2017

\begin{tabular}{|c|c|c|c|}
\hline Region & $\begin{array}{c}\text { GDP per citizen } \\
\text { in \% (current prices) }\end{array}$ & $\begin{array}{c}\text { Share in GDP generating in \% } \\
\text { (current prices) }\end{array}$ & $\begin{array}{c}\text { Unemployment } \\
\text { rate in \% }\end{array}$ \\
\hline Poland & 100 & - & 6.6 \\
\hline Warmian-Masurian & 70.4 & 2.6 & 11.7 \\
\hline Podlaskie & 71.8 & 2.2 & 8.5 \\
\hline Lublin & $\mathbf{6 8 . 9}$ & $\mathbf{3 . 8}$ & $\mathbf{8 . 8}$ \\
\hline Podkarpackie & $\mathbf{6 9 . 8}$ & $\mathbf{3 . 9}$ & $\mathbf{9 . 7}$ \\
\hline
\end{tabular}

Source: own study on the basis of data from GUS (Statistics Poland). 
The high unemployment rate and the low share in generating GDP characterising this area indicate the weakness of the potential of the local economy.

The shopping nature of border traffic on the border with Ukraine is determined primarily by the attractiveness of prices and the availability of a diversified product and service offer. According to GUS data, $87.3 \%$ of Ukrainians declared shopping as the purpose of their visit to Poland. It was the highest percentage among all foreigners crossing the Polish section of the EU external border.

Table 2.

The declared purpose of visit of the foreigners crossing Poland's eastern border in 2017

\begin{tabular}{|l|c|c|c|c|c|}
\hline \multirow{2}{*}{$\begin{array}{c}\text { Section of } \\
\text { border with: }\end{array}$} & \multicolumn{5}{|c|}{ Purpose of visit } \\
\cline { 2 - 6 } & Shopping & Leisure, recreation & Visiting family, friends & Transit & Business trip \\
\hline Russia & 65.9 & 13.2 & 3.0 & 10.4 & 4.9 \\
\hline Belarus & 83.6 & 1.8 & 7.1 & 4.1 & 2.3 \\
\hline Ukraine & $\mathbf{8 7 . 6}$ & $\mathbf{0 . 6}$ & $\mathbf{2 . 2}$ & $\mathbf{2 . 0}$ & $\mathbf{5 . 3}$ \\
\hline
\end{tabular}

Source: own study on the basis of data from GUS.

The factor prompting to make a purchase in Poland is the quality of products. Over $56 \%$ of the surveyed foreigners who visit border shopping centres indicated that products purchased in Poland had attractive prices and were of good quality (Malkowski, 2019).

As many as $46 \%$ of the surveyed entrepreneurs from Polish-Ukrainian border poviats indicated that foreigners constituted up to $40 \%$ of their clients. Over half of respondents indicated that the range of products and services they offered was tailored to the needs of buyers outside the EU.

Expenses related to shopping tourism are an important factor supporting the local economy. As many as $92 \%$ of the surveyed self-governments from the Polish-Ukrainian border indicated that border trade and border tourism were important for local development. This is reflected in the strategies of the surveyed local governments that relate to the use of the border location in the development of entrepreneurship and creation of new jobs.

The estimated value of goods and services purchased in Poland by foreigners in 2017 amounted to PLN 41.5 billion, and expenses incurred abroad by Polish residents PLN 20.1 billion.

In 2017, the citizens of Ukraine allocated the most for shopping in Poland. They spent over PLN 750 on the purchase of products and services per one person crossing the border. During the same period, Belarusians spent PLN 624 on purchases in Poland, Lithuanians PLN 532, Russians PLN 455, Germans PLN 461, Slovaks PLN 315, and Czechs PLN 285 per person. During the analysed period, in the case of the border with Ukraine, there was an increase in expenses incurred by foreigners in Poland, from PLN 734 in 2014 to PLN 750 in 2017.

The observations clearly show that expenses incurred by foreigners as part of border traffic are an important factor contributing to the development of the border area. In 2017, Ukrainian citizens spent over PLN 7 billion on purchases in Poland, of which PLN 852 million (11.6\%) was spent on food and alcohol. 
Non-food goods constituted the highest value in the expenses of foreigners crossing the eastern border of Poland. The Ukrainians spent PLN 6.6 billion (85.7\%) on their purchase.

The vast majority of expenses are incurred by foreigners within a $50 \mathrm{~km}$ range from the border. In the Polish-Ukrainian border area, 91\% of expenses of Ukrainian citizens in Poland are incurred at a distance of less than $50 \mathrm{~km}$ from the border $(89 \%$ within a $30 \mathrm{~km}$ range, respectively). This means that in an area $50 \mathrm{~km}$ away from the border with Ukraine, revenues related only to the shopping nature of cross-border travel of Ukrainian citizens to Poland are estimated to be at the level of over PLN 6 billion. This is an enormous sum that is generated only by shopping tourism.

\section{Conclusion}

The processes of integration and isolation that occur simultaneously pose a number of new socio-economic challenges for the Polish-Ukrainian border. Due to the peripheral nature of the region, it is among the most problematic areas in Poland, both in terms of its share in GDP generating and the volume of unemployment.

Changes in the border functions and the accompanying development of border traffic provide an opportunity to intensify the development of this area.

Developing shopping tourism is an opportunity to create favourable conditions for accelerating the socio-economic development of this region.

The study revealed that shopping tourism and the accompanying border trade can have a positive impact on the development of the Polish-Ukrainian border area. In particular, this applies to the area located within a $50 \mathrm{~km}$ range from the border, in which purchases of Ukrainians visiting Poland are concentrated. The development of shopping tourism will be possible thanks to creating a new dimension of the tourist product of border areas. It should undoubtedly be based on the development of border trade. It is necessary to monitor the motivations of the shopping tourists visiting the border area. This should improve the quality of tourist service and thus contribute to an increase in the quality of life in the region. 


\section{References}

1. Altkorn, J. (1995). Marketing w turystyce. PWN.

2. Barcelona Tourism for 2020. A collective strategy for sustainable tourism, https://ajuntament.barcelona.cat/turisme/sites/default/files/barcelona_tourism_for_2020.

3. Ciok, S. (2004). Pogranicze polsko-niemieckie. Problemy wspótpracy transgranicznej. Wrocław: WydawnictwoUniwersytetuWrocławskiego.

4. Hernik, J. (2014). Turystyczna konkurencyjność miasta-determinanty. Marketing i Rynek, $10(C D), 70-76$.

5. Hołderna-Mielcarek, B., Majchrzak, K. (2007). Strategia rozwoju turystyki zakupowej na przykładzie miasta Poznania. In: J. Mikołajczyk, Zarzadzanie usługami w gospodarce rynkowej: handel, gastronomia, turystyka. Poznań: WSHiU.

6. Kosiedowski, W. (2008). Regiony Europy Środkowo-Wschodniej w procesie integracji ze szczególnym uwzględnieniem wschodniego pogranicza Unii Europejskiej. Toruń: Wydawnictwo Naukowe Uniwersytetu Mikołaja Kopernika.

7. Malkowska, A. (2013). Strategia rozwoju euroregionu Pomerania a budowa konkurencyjnego regionu przygranicznego. Prace Naukowe Uniwersytetu Ekonomicznego we Wroclawiu, 307, 353-362.

8. Malkowska, A. (2014). Program INTERREG IV A jako instrument wspierania turystyki w województwie zachodniopomorskim. Prace Naukowe Uniwersytetu Ekonomicznego we Wrocławiu, 348, 181-189.

9. Malkowska, A. (2017). Eksport jako czynnik rozwoju województw zachodniego pogranicza Polski. Przedsiębiorczość i Zarzadzanie, 18(2.3), 57-75.

10. Malkowski, A. (2015). Koncepcje rozwoju społeczno-gospodarczego obszarów przygranicznych. Prace Naukowe Uniwersytetu Ekonomicznego we Wrocławiu, 402, 210-219.

11. Mazur, R. (2012). Plastyczność innowacji jako czynnik rozwoju branży turystycznej na obszarach o wysokim bezrobociu. Studia Ekonomiczne i Regionalne, 1, 86-90.

12. Miszczuk, A. (2013). Uwarunkowania peryferyjności regionu przygranicznego. Norbertinum.

13. Rojek, C., Urry, J. (2002). Transformations of travel and theory. Touring cultures. Routledge, 11-30.

14. Studzińska, D. (2014). Ruch bezwizowy a rozwój turystyki na pograniczu polskorosyjskim. Przeglad Geograficzny, 86(4), 525-540.

15. Timothy, D.J. (2005). Aspects of tourism. Shopping tourism, retailing and leisure. USA: Channel View Publications.

16. Timothy, D.J., Butler, R.W. (1995). Cross-border shopping. A North American perspective. Annals of Tourism Research, 22(1), 16-34.

17. Tosun, C., Temizkan, S.P., Timothy, D.J., and Fyall, A. (2007). Tourist shopping experiences and satisfaction. International Journal of Tourism Research, 9(2), 87-102. 
18. Turner, L.W., Reisinger, Y. (2001). Shopping satisfaction for domestic tourists. Journal of Retailing and consumer services, 8(1), 15-27.

19. UNWTO (2014). Global report on shopping tourism. World Tourist Organisation. AM Reports, 8.

20. Więckowski, M. (2010). Turystyka na obszarach przygranicznych Polsk, 224. IGiPZ PAN. 